\title{
Pemodelan Beban Pencemar Non-Point Source Sungai Premulung Segmen Kota Surakarta
}

\author{
Arya Rezagama ${ }^{1}$, Arief Laila $\mathbf{N}^{2}$, Affifah Nadya $\mathbf{A}^{1}$, Lia Setiawati ${ }^{1}$ \\ ${ }^{1)}$ Departemen TeknikLingkungan, Fakultas Teknik, Universitas Diponegoro, Jl. Prof. Soedarto, \\ SH, Kampus Undip Tembalang, Semarang, Indonesia 50275 \\ ${ }^{2)}$ Departemen Teknik Geodesi, Fakultas Teknik, Universitas Diponegoro, , Jl. Prof. Soedarto, \\ SH, Kampus Undip Tembalang, Semarang, Indonesia 50275 \\ E-mail : arya t/@ft.Undip.ac.id
}

\begin{abstract}
Abstrak
Sungai Premulung Kota Surakarta mendapatkan beban pencemaran dari sumber pencemaran tidak terpusat seperti limbah domestik dan limbah UKM limbah batik. Kualitas air sangat di pengaruhi oleh kondisi daerah aliran sungai dimana penelitian hubungan antara tata guna lahan dan kualitas sungai masih jarang diaplikasikan di Indonesia. Penelitian ini bertujuan untuk mengenalisis besaran beban pencemaran serta membandingkan secara spasial antara wilayah DAS premulung segmen Kota Surakarta. Survei kualitas air dilakukan dengan melakukan sampling 10 titik sepanjang sungai. Analisa spasial penggunaan lahan hasil dijitasi GIS citra Surakarta diolah dalam model BASIN-PLOAD. Berdasarkan hasil uji laboratorium nilai COD, Nitrat, Fosfat maupun tembaga (Cu), hampir keseluruhan segmen sungai masih dibawah baku mutu Kelas IV menurut PP no. 82 tahun 2001. Hasil model munjukkan penataan ruang memiliki korelasi yang sangat erat terhadap jumlah beban pencemaran yang masuk menuju sungai. Beban pencemar sumber bukan terpusat akan berhubungan lurus dengan luas wilayah dan area terbangun. Kelurahan Pajang Kecamatan Laweyan menempati urutan teratas dalam jumlah sumber pencemar dengan nilai $95 \mathrm{~kg} / \mathrm{tahun}$ untuk $\mathrm{Cu}, 1,097 \mathrm{~kg} / \mathrm{tahun}$ untuk fosfat, 534 kg/tahun untuk nitrat dan 2,042 kg/tahun untuk COD, kemudian diikuti Kelurahan Sondakan, Karangasem, dan Purwosari. Prioritas pengelolaan lingkungan Kota Surakarta dapat dibuat berdasarkan nilai beban pencemarannya.
\end{abstract}

Kata kunci : Analisa Spasial, Model Basin-PLOAD, Sumber Pencemar Tidak Terpusat

\begin{abstract}
Premulung River in Surakarta city recieves pollution load from non point source such as domestic waste and SME waste batik waste. Water quality is strongly influenced by watershed conditions where research on the relationship between land use and river quality is still rarely applied in Indonesia. This study aims to identify the amount of pollution load and to compare spatially between the Premulung Watershed segment of Surakarta. Water quality surveys were conducted by sampling 10 points along the river. Spatial analysis of land use resulted in GIS image of Surakarta is processed in BASIN-PLOAD model. Based on the results of laboratory tests of COD, Nitrate, Phosphate and copper, almost all segments of the river are still below the Class IV quality standard according to PP no. 82 of 2001. The model results show that spatial arrangement has a very close correlation to the amount of pollution load coming into the river. Non Point sources of pollutant burden will relate directly to the area and the fixed area. Pajang Sub-District Laweyan District occupied the top spot in the amount of pollutant source with the value of $95 \mathrm{~kg} /$ year for CU, 1,097 kg / year for phosphate, $534 \mathrm{~kg} /$ year for nitrate and 2,042 $\mathrm{kg} /$ year for COD followed by Sondakan, Karangasem and Purwosari Sub-districts. Surakarta environmental management priorities can be made based on the value of pollution load.
\end{abstract}

\section{Keywords : Spatial Analysis; Model Basin-PLOAD; Non Point Source}

\section{PENDAHULUAN}

Dewasa ini, daerah aliran sungai di seluruh dunia sedang memiliki masalah yang disebabkan oleh aktivitas manusia yang berlebihan. Urbanisasi yang tinggi mengeksploitasi siklus hidrologi DAS dan mengancam keberlanjutan suatu DAS (Lee, dkk., 2008). Keadaan bumi dalam decade terakhir, menjelaskan kerusakan perairan dalam dan pesisir memiliki kenaikan kerusakan yang tinggi disebabkan karena pelepasan nutrisi antropogenik seperti 
nitrogen dan fosfor ke air (Oliveira dkk., 2012). Begitu pula pertumbuhan perkotaan di Indonesia seperti di Kota Surakarta menimbulkan tekan pada kualitas air sungai.

Kota Surakarta merupakan daerah perkotaan yang padat penduduk. Aktivitas masyarakat di Kota Surakarta mayoritas adalah sebagai pedagang, perkantoran, dan industry. Bertumbuhnya aktivitas masyarakat akan sebanding dengan limbah yang dihasilkan oleh masyarakat tersebut. Hal tersebut menyebabkan penurunan kualitas lingkungan pada Sungai Bengawan Solo. Sungai Bengawan merupakan sungai terbesar yang berada pada Kota Surakarta. Sungai ini dimanfaatkan untuk sebagai irigasi pertanian, irigasi domestik, air baku pada PDAM, penanggulangan banjir dan lain-lain (Dani, Taufik, dkk., 2015). Salah satu sub DAS dengan hilir pada Sungai Bengawan Solo adalah Sungai Premulung, dimana merupakan salah satu sungai yang memiliki debit buangan limpasan air dari domestik, non domestik maupun limpasan yang cukup tinggi. (Sulistiyanto, Dwi . dkk., .2010).

Letak bantaran Sungai Premulung merupakan daerah dengan kepadatan penduduk yang tinggi dengan pembuangan limbah cair domestik dan non domestik yang langsung bermuara pada aliran sungai. Buangan pada sungai tersebut berasal dari limbah cair rumah tangga, limbah cair industri yang telah mencemari system Sungai Premulung. Hal itu dapat meningkatkan nilai COD, Nitrat, $\mathrm{Cu}$, dan Fosfat pada sungai tersebut (Prayitno, 2006; Imtiyaz dkk., 2016).

Penelitian yang memperhitungkan tentang pemodelan beban polutan sungai masih jarang. Seperti yang diketahui bahwa sebagian sungai di Indonesia memiliki karakteristik yang berbeda karena faktor iklim, geologi dan social ekonomi daripada Negara maju. Sumber limbah tidak hanya dari limbah domestik tetapi juga dari industri rumah tangga. Khusus pada industri rumah tangga berbeda-beda setiap lokasi dengan yang paling dominan adalah kain tradisional "batik". Ketika industri rumahan membuang limbah air tersebut akan secara langsung merubah morfologi dan ekologi pada suatu singai. Pemerintah Indonesia memiliki peraturan untuk menyesuaikan status kelas sungai dan menghitung beban pencemar dengan beberapa model salah satunya menggunakan Qual2E. Namun dalam prakteknya, alat tersebut tidak detail karena kurangnya masukan data dan sumber minimum yang ditetapkan (Oliveira dkk., 2012).
Ada berbagai sumper polusi yang menyebar dari setiap lokasi. Hampir sebagian penelitian sebelumnya memperhitungkan pencemaran sumber non titik menggunakan metode rasional. Jika kita melihat dari perencanaan tata ruang. Pemerintah Indonesia memiliki perturan tata ruang (RTRW) yang diatur untuk penggunaan lahan, dengan perencanaan pola ruang dimana bergunan sebagaii prediksi beban air pada setiap segmen atau lokasi tertentu. Model BASIN-PLOAD digunakan untuk memprediksi jumlah beban polutan dari sumber non titik berdasarkan data spasial. Dalam beberapa penelitian untuk kuantifikasi, beban polutan yang diekspor per satuan luas (tarif ekspor) yang terkait dengan masing-masing kategorii pendudukan tanah dianggap (Oliveira $d k k$., 2012). Nilai beban akan dihitung menjadii sumber pencemar tersebar hanya ketika beban sumber diangkut ke dalam aliran air. Jika tidak ada limpasan, tidak ada beban beban Non point source (NPS) di badan air terlepas dari ukuran populasi manusia, hewan atau unggas (Ongley, Xiaolan and Tao, 2010). Hasilnya sebagai EMC yang dapat menjadi bahan untuk input data untuk memproses beban polutan pada model PLOAD.

Penelitian ini bertujuan untuk memprediksi nilai beban pencemaran pada DAS Premulung segmen Surakarta secara spasial berdasarkan penggunaan tata ruang serta membandingkan setiap wilayah untuk mendapat prioritas. Kategorisasi nilai beban pencemaran dibuat dengan membandingkan tingkat dari yang tinggi, sedang rendah. Hal ini penting untuk melakukan evaluasi penantaan ruang berkonsep ekologi sungai. Penggunaan model ini dapat digunakan sebagai acuan dalam penetapan daya tampung sungai yang di ulas dalam instrumen Kajian Lingkungan Hidup Strategis (KLHS).

\section{METODOLOGI PENELITIAN}

Metode penelitian ini menggunakan pendekatan kualitatif dan kuantitatif. Tahapan pertama menganisis kondisi hidrologi Sungai Premulung.dengan mengumpulkan data sekunder, jurnal dan juga observasi secara langsung. Tahap kedua yaitu menganalisis karakteristik pencemar berdasarkan observasi lapangan dan hasil dari uji laboratorium. Tahap ketiga analisis beban pencemar menggunakan software Basins.

Pengambilan sampel dimulai dari batas wilayah Kota Solo Sungai Premulung hingga hilir mendekati Sungai Bengawan Solo. 
Sampel air diambil sebanyak 10 sampel dengan kombinasi anak sungai kemudian akan di analisa kadar COD, Cu, Phosphat, dan nitrat. Analisi kualitas sungai di uji berdasarkan metode SNI. Penelitian dilakukan pada bulan Agustus hingga Oktober 2017.

BASIN - PLOAD adalah model yang digunakan dalam mensimulasidistribusi Integrasi pencemar Poin dan bukan Titik Sumber yang dikembangkan oleh Environmental Protection Agency (EPA). PLOAD juga dapat dimaksudkan sebagai model yang disederhanakan dalam basis model GIS yang diperuntukkan untuk menghitung beban polutan pada daerah aliran sungai (DAS). PLOAD memperkirakan sumber-sumber pencemar non titik (NonPoint Source) pada basis rata-rata tahunan, untuk setiap polutan yang ditentukan oleh pengguna.

Perhitungan beban non-titik (NPS) menggunakan metode sederhana (The Export Coefficient) (Lin dkk., 2016). Metode Sederhana (The Simple Method) adalah pendekatan empiris yang digunakan untuk memperkirakan beban polutan tahunan dari tingkat pemuatan berdasarkan penggunaan lahan yang ditetapkan sebagai pencemar massal perlimpasan unit. Awalnya dikembangkan untuk memperkirakan beban polutan untuk situs pembangunan perkotaan di daerah Washington, DC. (HDR, 2008).

Metode Sederhana ditunjukan untuk menghitung beban polutan dalam LOAD, kemudian dua persamaan diperlukan untuk menghitung beban untuk setiap jenis polutan tertentu. Pertama, dalam perhitungan koefisien limpasan untuk setiap jenis penggunaan lahan yang diturunkan dengan persamaan :

RVU =0,05 $+(0.009 * \mathrm{IU})$
$\begin{array}{ll}\text { Dimana: } \\ \text { RUV } & \text { Koefisien Limpasan untuk } \\ & \begin{array}{l}\text { penggunaan lahan tipe u, } \\ \text { (inchesrun/inchesrain) }\end{array} \\ & =\text { Persen kelolosan air }\end{array}$

Sumber Pencemar dihitung dengan mengikuti persamaan:

$L P=\Sigma U\left(P *{ }^{*} J^{*} R V U\right.$ * $C U^{*} A U$ * $\left.2.72 / 12\right)$

Dimana:

LP =Sumber Polutan (lbs)

$\mathrm{P} \quad$ =Presipitasi (Inches/Tahun)

PJ =Rasio dari limpasan Hujan saat Deras $($ default $=0.9$ )
RVU =Koefisien Limpasan dari Penggunaan Lahan type u (Inches run/Inches rain)

$\mathrm{CU}=$ Even Mean Concentration dari penggunaan lahan type $u$ (milligrams/liter)

$\mathrm{AU} \quad=$ Area dari penggunaan lahan tipe $\mathrm{u}$, acres (dalam area BASINS diperhitungkan dari dara GIS dalam square meter.

PLOAD mengubah area dari meter persegi menjadi hektar sebelum menggunakan informasi dalam persamaan di atas. (USEPA, 2001)PLOAD menghasilkan output grafis dan tabular. Output grafis termasuk peta dengan DAS untuk wilayah studi, dilambangkan dengan warna per batas DAS, yang menggambarkan total polutan $\mathrm{lb} /$ tahun. (Young, 2006).

Model PLOAD perhitungan beban pencemar dikategorikan menjadi dua, yaitu Expert Coefficient dan juga Simple (EMC) .(Jeff $P, 2004)$ Pada penelitian ini menggunakan Simple (EMC) karena merupakan kategori perhitungan beban pencemaran dengan karakteristik didalamnya merupakan karakter yang sama dengan Kota Surakarta. Masukan data yang akan digunakan untuk menghitung beban pencemar yaitu event mean concentration (nilai EMC). Nilai EMC ini merupakan pendekatan pada masing-masing cateegori tataguna lahan. Nilai EMC ini akan bekerja dalam perhitungan beban polutan pada pada software BASINS.(CH2M HILL, 2001; Jeff P, 2004; RATIDZO, 2011). Nilai EMC sesuai dengan jenis tata guna lahan dapat dilihat pada Tabel 1.

Tahap terakhir adalah membuat klasifikasi hasil dari model PLOAD menggunakan ArcGIS dengan mode Standar Deviasi. Standard Deviasi merupakan salah satu pilihan pada classify simbology pada ArcGIS yang berfungsi untuk menghitung rata-rata dan kemudian menghasilkan kelas rage dengan bertututturut menambahkan atau mengurangkannya dari standar deviasi. Dua tingkat atau lebih merupakan bantuan untuk memberikan tampilan nilai dengan warna yang berbeda dimana menunjukkan tingkat yang lebih tinggi dari standar awal yang ditetapkan nilainya. Standar deviasi ini baik digunakan pada data terdistribusi normal. (PAPPAS, 2013). 


\section{HASIL DAN PEMBAHASAN}

Segmentasi pada Sungai Premulung ini dibagi menjadi 6 segmentasi dengan jumlah titik pengambilan sampel pada sungai yaitu 10 titik dengan detail 4 titik diambil pada input anak sungai / drainase dan 6 titik lainnya merupakan badan air sungai

Tabel 1. Nilai EMC pada Model Pload

\begin{tabular}{|c|c|c|c|c|c|c|c|}
\hline Tata Guna Lahan & Impervious & Patogen & $\mathrm{BOD}$ & COD & Fosfat & Nitrat & $\mathrm{CU}$ \\
\hline Aneka Industri & 86,6 & 1400 & 17,2 & 0,39 & 0,31 & 1,79 & 0,50 \\
\hline Danau/Situ/Telaga & 100 & 500 & 1,6 & 0,78 & 0,11 & 1,25 & 0,00 \\
\hline Jasa Kesehatan & 98 & 1400 & 17,2 & 0,39 & 0,43 & 2,83 & 0,40 \\
\hline Jasa Keuangan & 98 & 1400 & 17,2 & 0,39 & 0,43 & 2,83 & 0,40 \\
\hline Jasa Lainnya & 91 & 1400 & 8,2 & 0,39 & 0,15 & 1,18 & 0,40 \\
\hline Jasa Pariwisata & 98 & 1400 & 17,2 & 0,39 & 0,43 & 2,83 & 0,40 \\
\hline Jasa Pendidikan & 98 & 1400 & 17,2 & 0,39 & 0,43 & 2,83 & 0,40 \\
\hline $\begin{array}{l}\text { Jasa Perhubungan/ } \\
\text { Transport }\end{array}$ & 98 & 1400 & 17,2 & 0,39 & 0,43 & 2,83 & 0,40 \\
\hline Jasa Peribadatan & 91 & 1400 & 8,2 & 0,39 & 0,43 & 2,83 & 0,40 \\
\hline Jasa Profesi & 98 & 1400 & 17,2 & 0,39 & 0,43 & 2,83 & 0,40 \\
\hline Jasa Telekomunikasi & 98 & 1400 & 17,2 & 0,39 & 0,43 & 2,83 & 0,40 \\
\hline Kampung Padat Teratur & 67 & 8700 & 11 & 0,55 & 0,49 & 2,42 & 0,14 \\
\hline $\begin{array}{l}\text { Kampung Padat Tidak } \\
\text { Teratur }\end{array}$ & 28 & 8700 & 7,4 & 0,55 & 0,30 & 2,29 & 0,14 \\
\hline Kebun Campuran & 2 & 15000 & 3,8 & 0,58 & 0,48 & 2,48 & 0,10 \\
\hline Kuburan/Pemakaman & 2 & 1400 & 1,45 & 0,78 & 0,05 & 1,25 & 0,10 \\
\hline Lapangan Olahraga & 2 & 1400 & 8,2 & 0,58 & 0,15 & 1,18 & 0,40 \\
\hline Perbengkelan & 91 & 1400 & 8,2 & 0,58 & 0,15 & 1,18 & 0,40 \\
\hline Perumahan Jarang & 15 & 8700 & 4,4 & 0,55 & 0,18 & 1,77 & 0,14 \\
\hline Perumahan Padat & 15 & 8700 & 4,4 & 0,55 & 0,18 & 1,77 & 0,14 \\
\hline Taman Umum & 2 & 2400 & 1,45 & 0,78 & 0,56 & 1,25 & 0,10 \\
\hline Tanah Terbuka Lainnya & 2 & 15000 & 1,45 & 0,78 & 0,56 & 1,25 & 0,10 \\
\hline Tempat Bersejarah & 2 & 1400 & 1,45 & 0,39 & 0,05 & 1,25 & 0,40 \\
\hline Jalan Aspal & 86 & 500 & 5,6 & 0,39 & 0,34 & 2,08 & 0,04 \\
\hline Jasa Instansi Pemerintah & 98 & 1400 & 17,2 & 0,39 & 0,43 & 2,83 & 0,40 \\
\hline Jasa Perdagangan & 98 & 1400 & 17,2 & 0,39 & 0,43 & 2,83 & 0,40 \\
\hline $\begin{array}{l}\text { Sawah Irigasi 2x } \\
\text { Padi/Tahun }\end{array}$ & 2 & 15000 & 3,8 & 0,78 & 0,34 & 2,32 & 0,10 \\
\hline Sungai & 100 & 500 & 1,6 & 0,78 & 0,11 & 1,25 & 0,10 \\
\hline
\end{tabular}

Tabel 2. Segmentasi Sungai Premulung

\begin{tabular}{|c|c|c|c|c|c|c|c|}
\hline \multirow{2}{*}{ No } & \multirow{2}{*}{ Nama Segmen } & \multirow{2}{*}{$\mathrm{Km}$} & \multirow{2}{*}{$\begin{array}{c}\text { Panjang } \\
(\mathrm{Km})\end{array}$} & \multicolumn{2}{|c|}{ Elevasi } & \multicolumn{2}{|c|}{ Koordinat } \\
\hline & & & & Hulu & Hilir & Hulu & Hilir \\
\hline 1 & $\begin{array}{l}\text { Karang Asem - } \\
\text { Laweyan }\end{array}$ & $\begin{array}{l}5.69 \mathrm{~s} / \mathrm{d} \\
3.48\end{array}$ & 1.91 & 108 & 103 & $\begin{array}{l}7^{\circ} 33^{\prime} 28^{\prime \prime S} \\
110^{\circ} 46^{\prime} 45.16 " \mathrm{E}\end{array}$ & $\begin{array}{l}07^{\circ} 34^{\prime} 06.6^{\prime \prime} \mathrm{S} \\
110^{\circ} 47^{\prime} 24.8^{\prime \prime E}\end{array}$ \\
\hline 2 & Laweyan & $\begin{array}{l}3.48 \mathrm{~s} / \mathrm{d} \\
2.31\end{array}$ & 0.4 & 103 & 102 & $\begin{array}{l}07^{\circ} 34^{\prime} 06.6^{\prime \prime} \mathrm{S} \\
110^{\circ} 47^{\prime} 24.8^{\prime \prime E}\end{array}$ & $\begin{array}{l}07^{\circ} 34^{\prime} 16.0^{\prime \prime} \mathrm{S} \\
110^{\circ} 47^{\prime} 34,0^{\prime \prime} \mathrm{E}\end{array}$ \\
\hline 3 & Lawyan- Panularan & $\begin{array}{l}2.31 \mathrm{~s} / \mathrm{d} \\
1.95\end{array}$ & 2.41 & 102 & 97 & $\begin{array}{l}07^{\circ} 344^{\prime} 16.0^{\prime \prime} \mathrm{S} \\
110^{\circ} 47^{\prime} 34,0^{\prime \prime} \mathrm{E}\end{array}$ & $\begin{array}{l}7^{\circ} 34^{\prime} 22.5^{\prime \prime S} \\
110^{\circ} 48^{\prime} 14.9^{\prime \prime} \mathrm{E}\end{array}$ \\
\hline 4 & Panularan-Tipes & $\begin{array}{l}1.95 \mathrm{~s} / \mathrm{d} \\
1.15\end{array}$ & 1.2 & 97 & 95 & $\begin{array}{l}7^{\circ} 34^{\prime} 22.5^{\prime \prime S} \\
110^{\circ} 48^{\prime} 14.9^{\prime \prime} \mathrm{E}\end{array}$ & $\begin{array}{l}07^{\circ} 34.4^{\prime} 42.1^{\prime \prime} \\
\mathrm{S} 110^{\circ} 47^{\prime} 34,0^{\prime \prime E}\end{array}$ \\
\hline 5 & $\begin{array}{l}\text { Tipes- } \\
\text { Donokusuman }\end{array}$ & $\begin{array}{l}1.15 \mathrm{~s} / \mathrm{d} \\
0.74\end{array}$ & 0.6 & 95 & 94 & $\begin{array}{l}07^{\circ} 34.4^{\prime} 42.1^{\prime \prime} \\
\text { S110 } 10^{\circ} 47^{\prime} 34,0^{\prime \prime E}\end{array}$ & $\begin{array}{l}07^{\circ} 35^{\prime} 0.2^{\prime \prime} \mathrm{S} \\
110^{\circ} 48^{\prime} 21.9^{\prime \prime} \mathrm{E}\end{array}$ \\
\hline 6 & $\begin{array}{l}\text { Donokusuman- } \\
\text { Joyosuran }\end{array}$ & $\begin{array}{l}0.74 \mathrm{~s} / \mathrm{d} \\
0.00\end{array}$ & 1.21 & 94 & 93 & $\begin{array}{l}07^{\circ} 35^{\prime} 0.2^{\prime \prime} \mathrm{S} \\
110^{\circ} 48^{\prime} 21.9^{\prime \prime} \mathrm{E}\end{array}$ & $\begin{array}{l}07^{\circ} 35^{\prime} 13^{\prime \prime} \mathrm{S} \\
110^{\circ} 49^{\prime} 54,9^{\prime \prime} \mathrm{E}\end{array}$ \\
\hline
\end{tabular}

premulung. Tabel 2 menunjukkan data segmentasi pada sungai Premulung. Berdasarkan hasil sampling air, kondisi fisik air telah berwarna, keruh dan berbau. Peta administrasi cakupan wilayah penelitian dan titik pengambilan sampel dapat dilihat pada

\section{Gambar 1.}

(29.

39 Jurnal Presipitasi : Media Komunikasi dan Pengembangan Teknik Lingkungan, Vol. 15 No.1 Maret 2018 


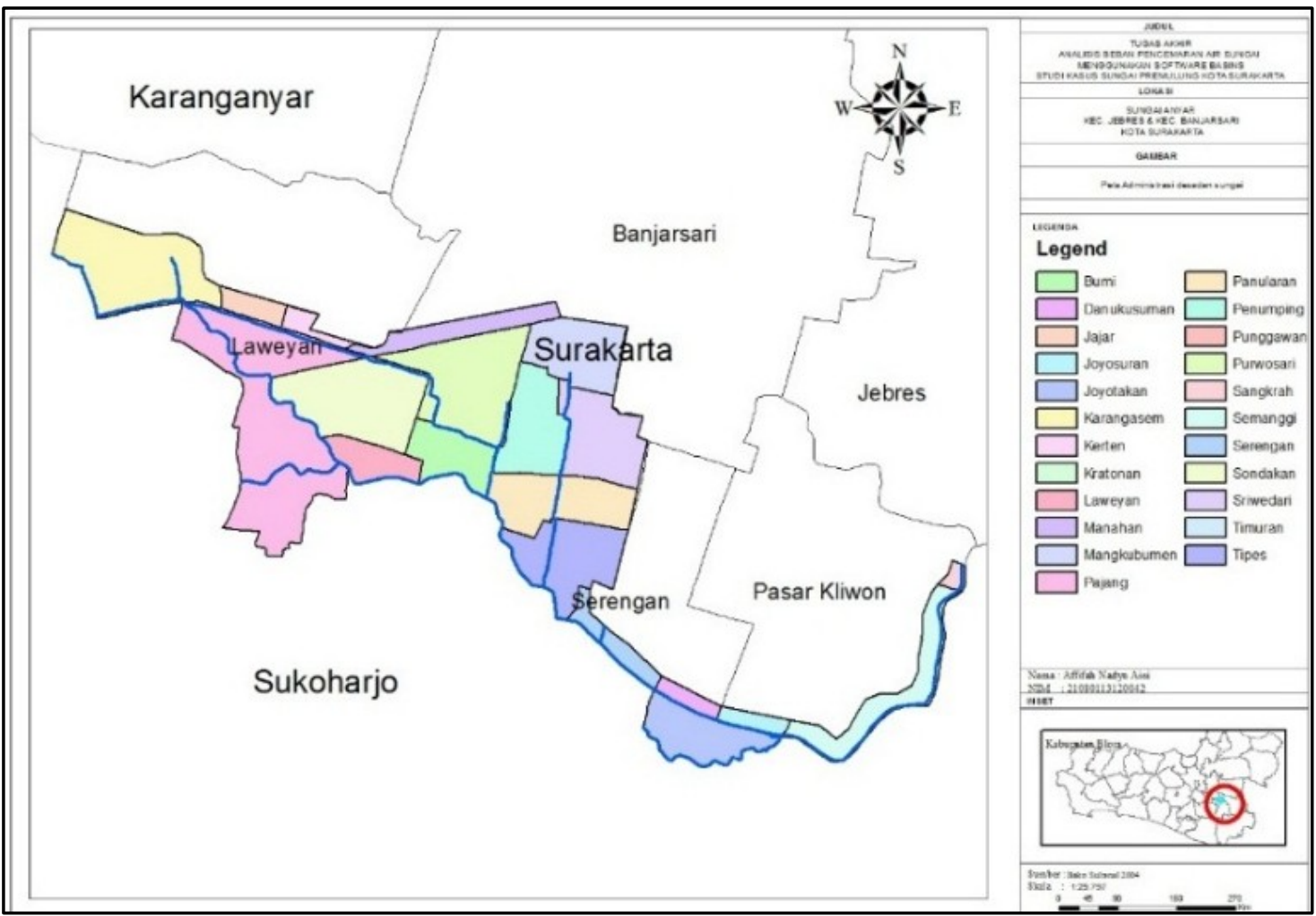

Gambar 1. Peta Administrasi Cakupan Wilayah Penelitian dan Titik Pengambilan Sampel

Kualitas Air Sungai Bengawan Solo berdasarkan parameter yang digunakan pada analisis kualias air Bengawan Solo adalah parameter kunci sesuai dengan Peraturan Pemerintah Nomor 82 Tahun 2001 tentang Pengelolaan Kualitas dan PengendalianPencemaran Air. Parameter kunci didasarkan pada indikasi sumber pencemar pada daerah tersebut, diantaranya BOD, Nitrat, Fosfat dan Tembaga (Cu).

\section{$C O D$}

Berdasarkan hasil uji laboratorium untuk parameter pencemaran COD, Phosphat, $\mathrm{Cu}$, dan Nitrat menunjukan bahwa Sungai Premulung memenuhi peruntukan kelas IV untuk baku mutu air PP No. 82 Tahun 2001. Berdasarkan data analisis laboratorium, nilai COD pada hulu Sungai Premulung atau Titik 1 hingga titik terakhir mengalami fluktuatif. Nilai COD yang tertinggi ada pada titik 6 yakni sebesar $173 \mathrm{mg} / \mathrm{L}$ yang berada pada anak sungai/drainase Sungai Premulung.

Sesuai Baku mutu kelas 4 sebesar 100 $\mathrm{mg} / \mathrm{L}$, titik yang memiliki nilai cemaran COD melebihi baku mutu kelas IV, yaitu Titik 4, 5, dan 6 dengan nilai $112,7 \mathrm{mg} / \mathrm{L}, 102,7 \mathrm{mg} / \mathrm{L}$, dan $173 \mathrm{mg} / \mathrm{L}$.
Berdasarkan hasil observasi lapangan pada Gambar 2, masyarakat dibantaran Sungai Premulung melakukan pembuangan kesungai pada saat menjelang sore sekitar jam 2 atau 3. Peneliti saat mengambil air sampel yaitu pada jam 10-11 siang. Hal tersebut mengartikan telah terjadinya pengenceran sehingga nlai konsentrai COD menurun (Imtiyaz $d k k$. 2016). Nilai COD pada Running Software Basin dapat dilihat pada Gambar 3.

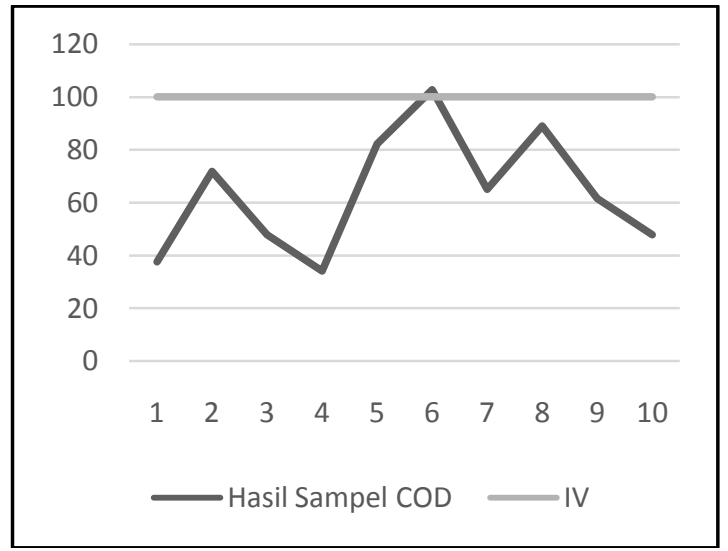

Gambar 2. Grafik Kondisi COD Sungai Premulung dan Baki Mutu PP no 82 Tahun 2001 


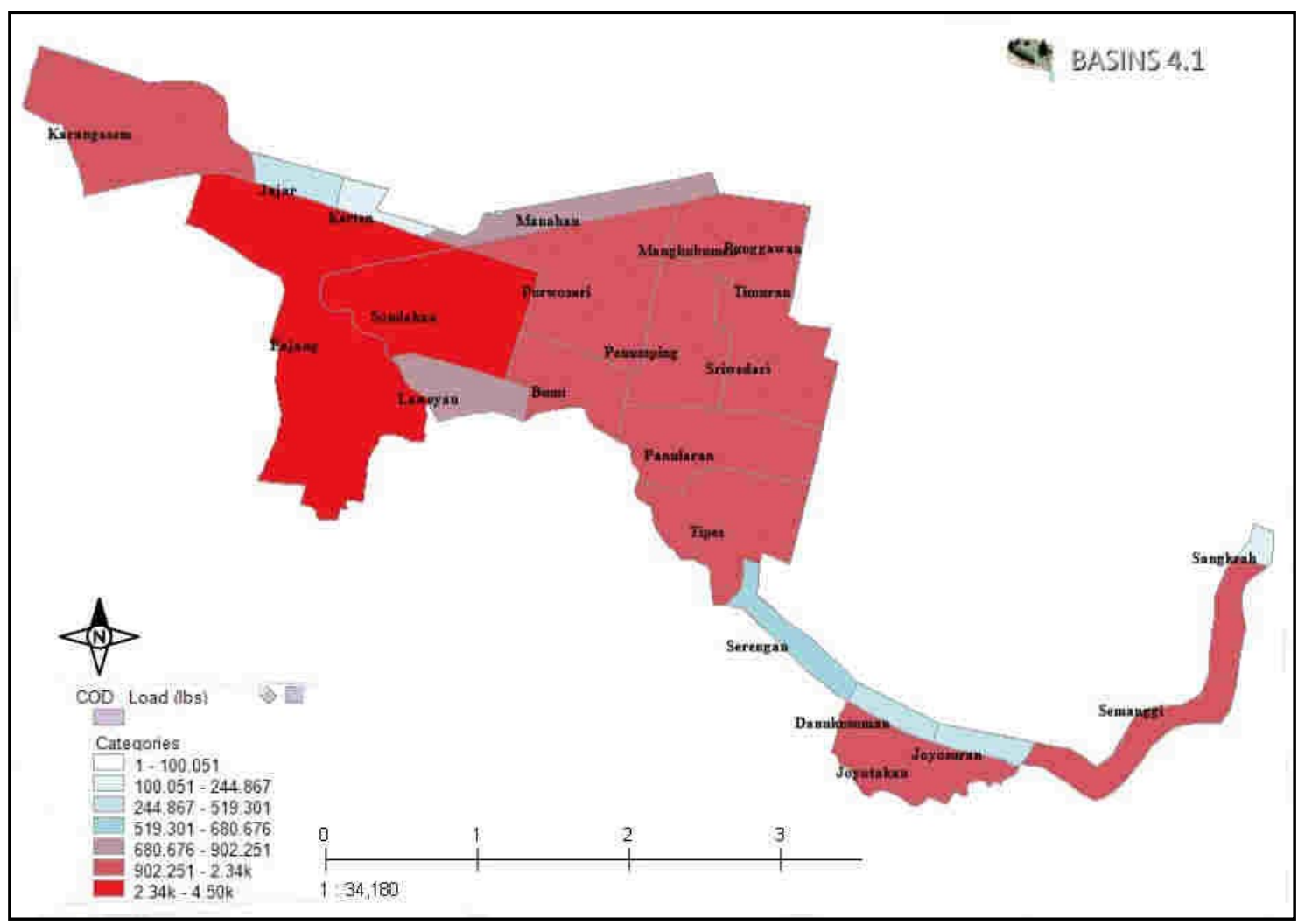

Gambar 3. Nilai COD pada Running Software Basin

Fosfat

Berdasarkan hasil uji kualitas air (Gambar 4) diketahui bahwa kadar fosfat memenuhi Standar Baku Mutu Kelas IV. Nilai fosfat sangat penting bagi kesuburan tumbuhan dan metabolisme mikroorganisme yang merupakan indikator untuk mengevaluasi kualitas dan tingkat kesuburan perairan (Simon dkk., 2015).

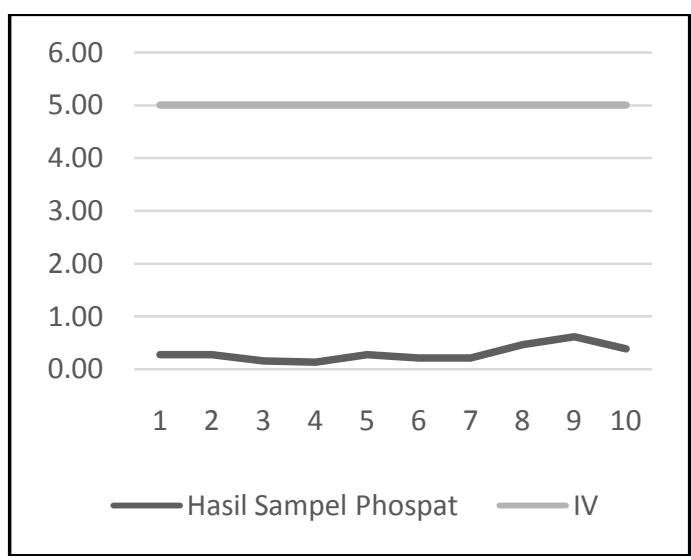

Gambar 4. Grafik Kondisi Fosfat Sungai Premulung dan Baki Mutu PP no 82 Th 2001

Nilai konsentrasi fosfat tertinggi ada pada Titik 9 dengan nilai $0,610 \mathrm{mg} / \mathrm{L}$. Sumber utama penyumbang fosfat ke dalam suatu perairan adalah limbah domestik masyarakat. limbah tersebut termasuk detergen berbahan dasar fosfat. Secara umum kadar fosfat rata-rata di perairan berkisar antara 0,101-0,202 mg/L yang menunjukkan tingkat kesuburan (Simon dkk., 2015). Nilai Fosfat pada Running Software Basin dapat dilihat pada Gambar 7.

Nitrat

Kadar nitrat di perairan Sungai Premulung sangat beragam (Gambar 5). Kadar terendah yaitu pada hilir sebesar 2,55 $\mathrm{mg} / \mathrm{L}$ sedangkan kadar paling tinggi berada pada Titik 2 yaitu sebesar $26,21 \mathrm{mg} / \mathrm{L}$. Perbandingan parameter nitrat dengan baku mutu kualitas air PP No. 82 Tahun 2001, dimana hampir semua sampel yang diuji akan memenuhi baku mutu kualitas air pada kelas III.

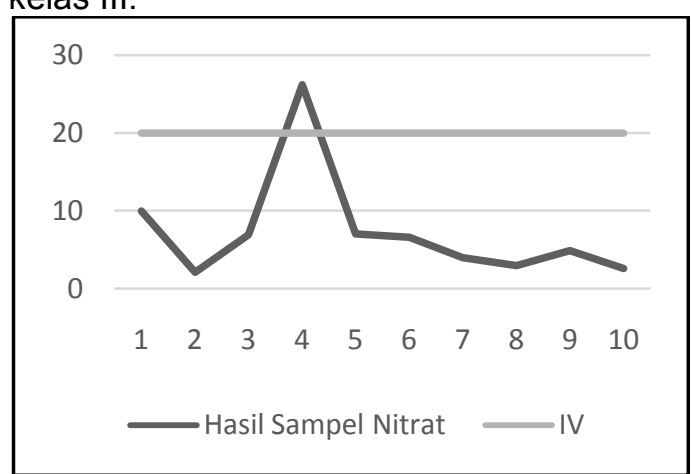

Gambar 5. Grafik Kondisi Nitrat Sungaii Premulung dan Baki Mutu PP no 82 Th 2001 
Menurut Seitzinger (1998) sedimen yang terdapat pada wilayah lapisan permukaan lapisan merupakan tempat penyimpan utama nitrat. Nitrat yang berada pada sedimen diproduksi dari biodegradasi bahan-bahan yang selanjutnya dioksidasi menjadi nitrat (Simon I dkk., 2015). Nilai Nitrat pada Running Software Basin dapat dilihat pada Gambar 6.

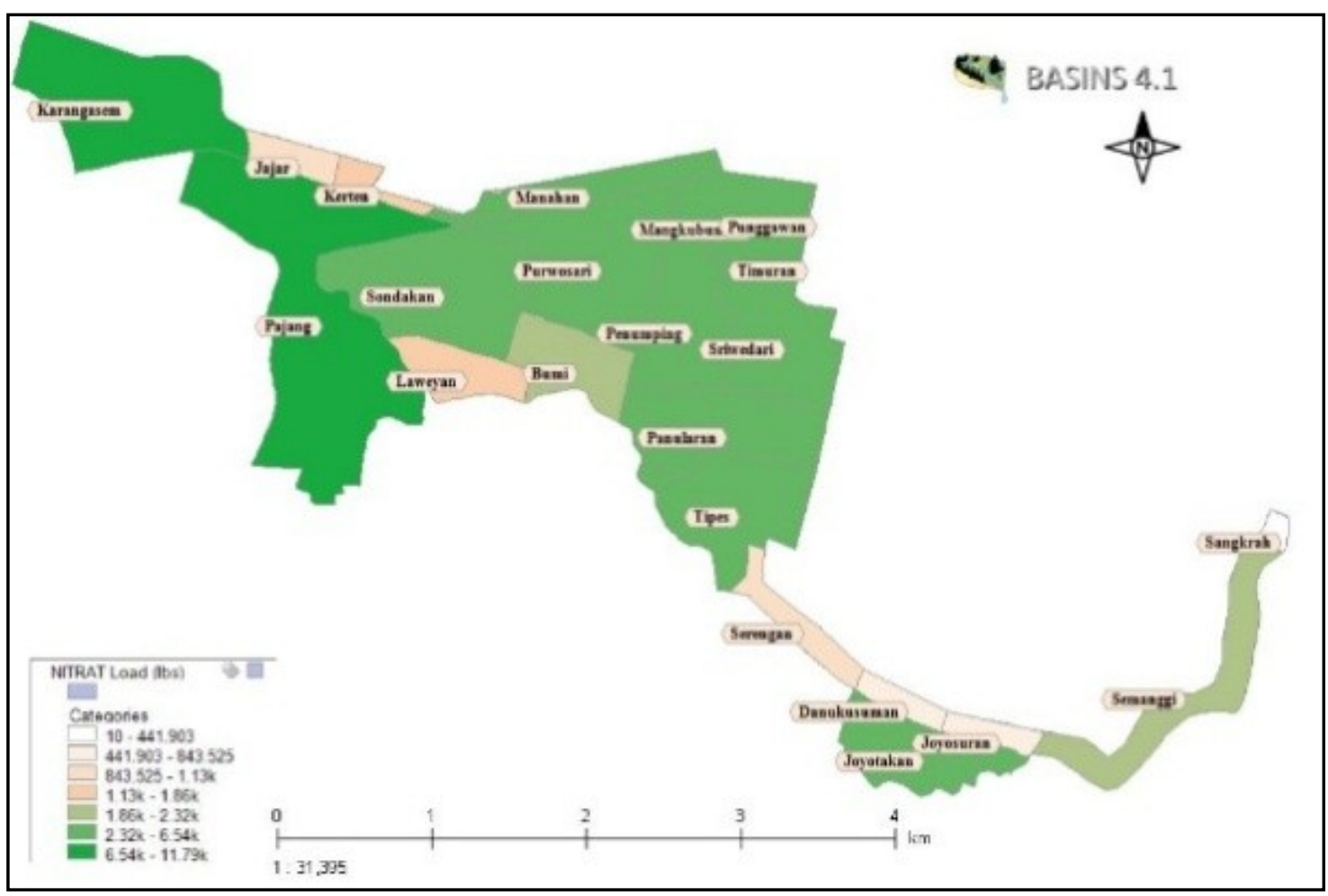

Gambar 6. Nilai Nitrat pada Running Software Basins

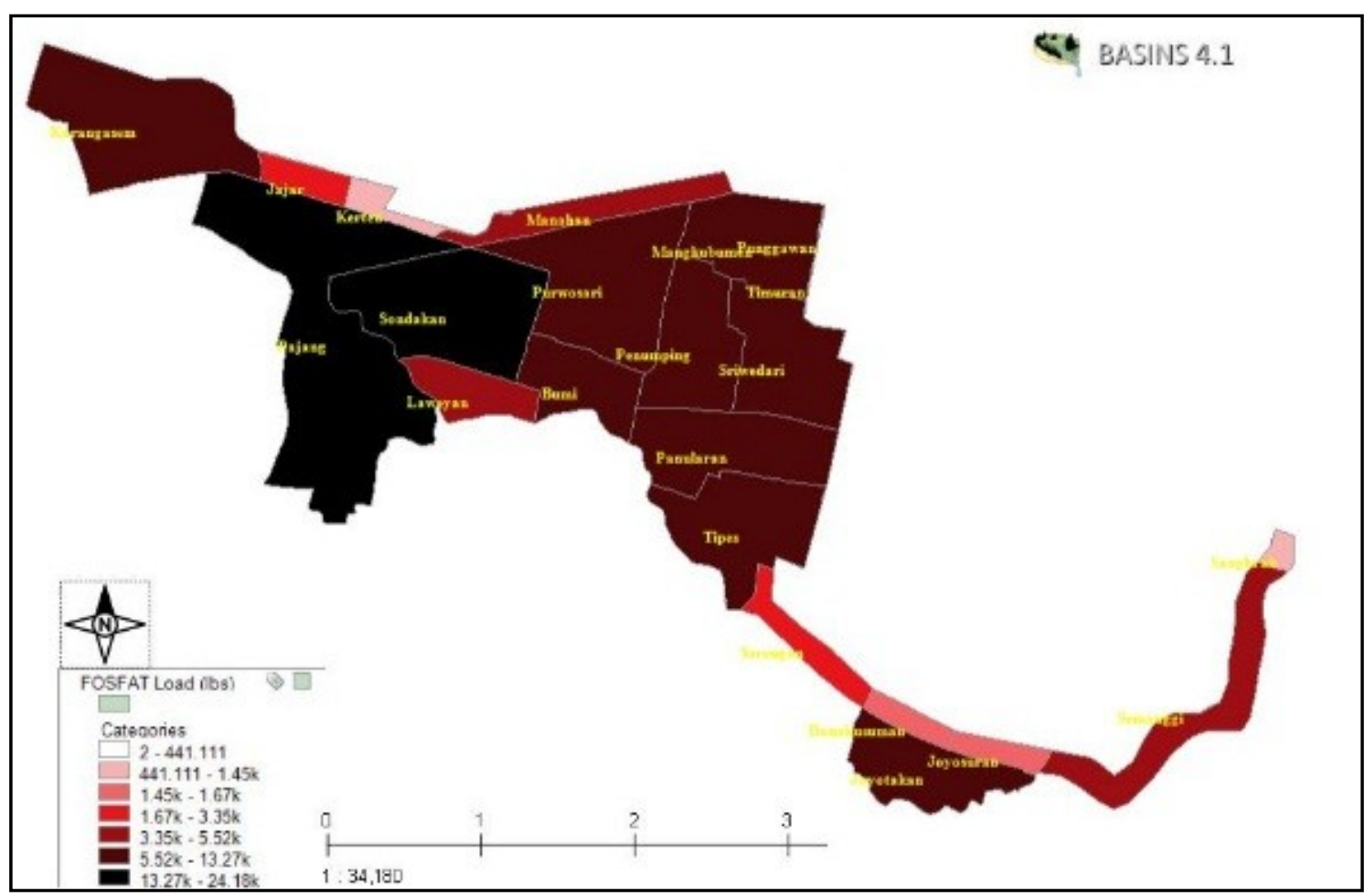

Gambar 7. Nilai Fosfat pada Running Software Basins 
$\mathrm{Cu}$

Terdeteksinya kandungan logam $\mathrm{Cu}$ pada suatu sungai dapat disebabkan oleh beberapa hal. Salah satunya bisa karena berada pada perairan yang berdekatan dengan pemukiman penduduk.

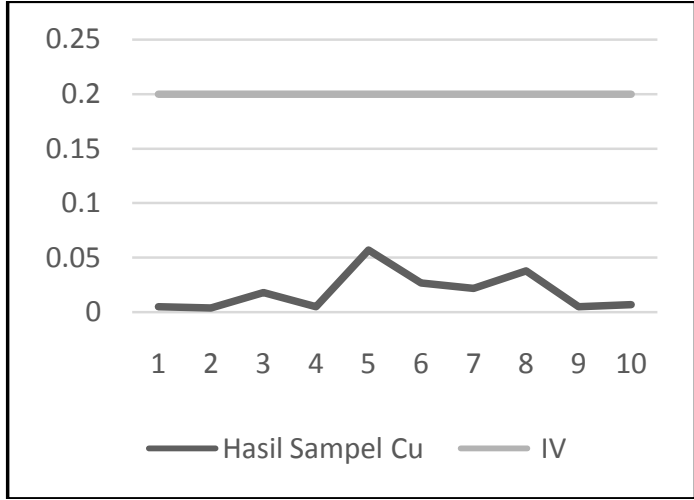

Gambar 8. Grafik Kondisi Cu Sungai Premulung dan Baki Mutu PP no 82 Th 2001

Hasil kadar $\mathrm{Cu}$ yang tertinggi berada pada Titik 3 yaitu $0,057 \mathrm{mg} / \mathrm{L}$ dan Titik 4 yaitu 0,051 $\mathrm{mg} / \mathrm{L}$. Pada titik tersebut terdapat IPAL yang tidak berfungsi dengan semestinya dan juga beberapa UKM batik yang langsung membuang limbahnya pada aliran sungai.

Dapat dilihat pada Gambar 8 kandungan kadar $\mathrm{Cu}$ pada Sungaii Premulung tidak terlalu tinggi namun tetap memiliki muatan. Fluktuasi konsentrasi logam berat dapat dipengaruhi oleh masuknya buangan yang mengandung logam berat seperti limbah industri, limbah domestik dan limbah pertanian(Rahmad, Yunasfi and Maragunung, 2014)

Kelurahan yang berada pada aliran Sungai Premulung yang memiliki tingkat pencemaran tertinggi berada pada Kelurahan Laweyan, Kelurahan Bumi, dan Kelurahan Panularan yang merupakan kelurahan dengan mayoritas aktivitas penduduknya sebagai industri batik dan jasa. Hal tersebut memiliki dampak pada keadaan fisik sungai yang pada waktu tertentu mengalami perubahan warna dan bau yang tidak sedap. Nilai $\mathrm{Cu}$ pada Running Software Basin dapat dilihat pada Gambar 9. Analisa beban cemaran COD terbesar berasal dari Kelurahan Pajang dan Sondokan, Kecamatan Laweyan yakni sebesar 2,042 kg/tahun dan 1060 kg/tahun.

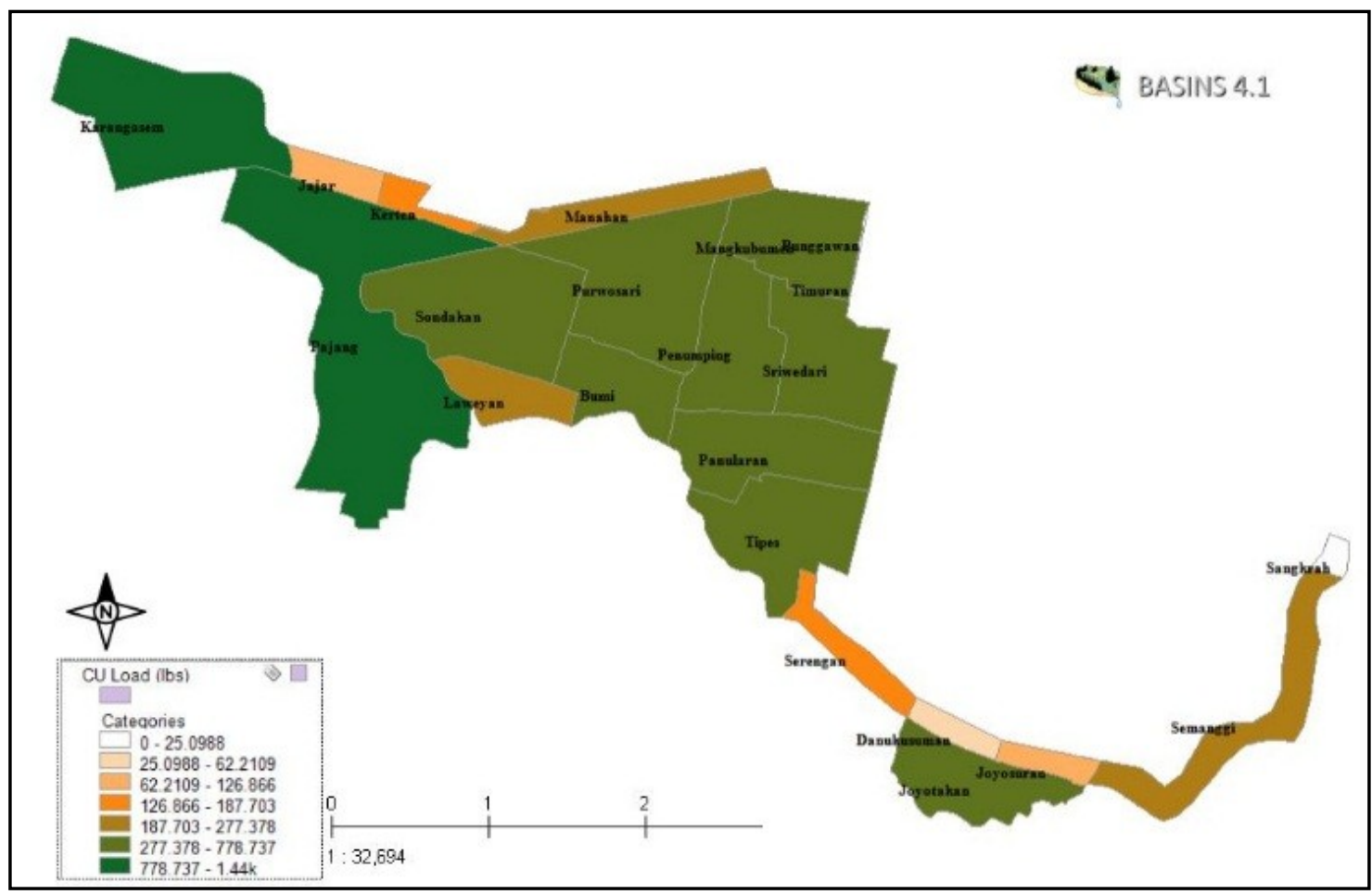

Gambar 9. Nilai Cu pada Running Software Basin

Pada kelurahan laweyan terdapat pertemuan anatara dua sungai yaitu Premulung Hulu dan Sungai Brojo. Sungai Brojomemiliki tingkat pencemaran yang sangat tinggi berasal dari daerah karangnyar berwarna hitam pekat.
Sedangkan Premulung hulu nampak hanya membawa material erosi saja berwarna coklat. Karakterisitk limbah teksil dapat dilihat pada saat awal keluar dari tempat produksi maka warna pada sungai akan nampak sangat kuat seperti aslinya misal merah, kuning, hijau, dll. Setelah beberapa 
kilometer mengalir maka warna akan berubah menjadi hitam yang dimungkinkan akibat teradsorpsinya warna ke padatan tersuspensi sungai serta lilin yang ikut mengalir. Kemudian pada jarak tertentu padatan tersebut akan mengendap di dasar sungai pada aliran rendah sehingga nampak warna akan normal kembali. Endapan yang menumpuk di dasar sungai berupa lumpur hitam pekat membuat pendangkalan dan permasalahan lingkungan yang serius.

Nilai fosfat tertinggi berada pada kelurahan Pajang yang berada pada Kecamatan Laweyan sebesar dengan 1,097 kg/tahun. Nilai terkecil berada pada Kelurahan Kerten yang berada pada Kecamatan Laweyan senilai 20 kg/tahun. Hal tersebut dikarenakan catchment area pada daerah Kerten memiliki luasan terkecil, Sehingga hanya sebagian kecil dari bagian Kelurahan Kerten yang membuangan limbahnya pada aliran DAS Premulung.

Kadar nitrat tertinggi berada pada Kelurahan pajang, Kecamatan Laweyan yakni dengan besaran 534 kg/tahun. Sedangkan nilai nitrat terkecil berada pada Kelurahan Sangkrah pada Kecamatan Pasar Kliwon yakni sebesar $7 \mathrm{~kg} /$ tahun. Unsur nitrat merupakan unsur primer yang biasa terkandung pada tanah. Ketersediaan unsur nitrat pada suatu kawasan merupakan suatu indikasi untuk menilai dan mengevaluasi tingkat produktivitas atau kesuburan perairan yang bersangkutan. (Sanusi, 1994). Jika nilai nitrat tinggi maka akan terjadi denitrifikasi di perairan tersebut dan pelepasan unsur $\mathrm{N}$ ke atmosfer. (Correll, 1998)

Beban cemaran pada parameter tembaga $(\mathrm{Cu})$ dengan nilai tertinggi terdapat pada Kelurahan Karangasem dan Kelurahan Pajang dengan $35 \mathrm{~kg} / \mathrm{tahun}$ atau 95 $\mathrm{kg} /$ tahun. Logam tembaga yang masuk ataupun dimasukkan ke dalam lingkungan perairan dapat menjadikan secara alamiah mendapatkan efek samping dari kegiatan manusia. Kejadian yang akan terjadi ketika logam tembaga masuk ke dalam suatu perairan yaitu peristiwa erosi, pengikisan batuan ataupun dari atmosfer yang dibawa turun oleh air hujan. Sedangkan efek dari aktivitas industri menyebabkan meningkatnya keluaran tembaga dalam perairan. (Rahmad, Yunasfi and Maragunung, 2014)

Hasil model menunjukkan bahwa kelurahan Pajang mendominasi dari seluruh aspek pencemaran kemudian diikuti Kelurahan Sondakan, Karangasem, dan Purwosari. Kecamatan Laweyan memiliki 55
Kosan, 32 Hotel, dan 81 UKM Batik. Selain usaha kosan, hotel, UKM batik. Sedangkan untuk kelurahan Pajang sebagai penyumbang terbesar semua parameter memiliki 11,5 ha area komersial dan jasa, 15,9 Ha lahan campuran terbangun, 103,8 $\mathrm{Ha}$ area pemukiman yang terluas di banding kelurahan yang lain. Maka prioritas pengelolaan lingkungan Kota Surakarta dapat dibuat berdasarkan nilai beban pencemarannya.

\section{KESIMPULAN}

Penataan ruang memiliki korelasi yang sangat erat terhadap jumlah beban pencemaran yang masuk menuju sungai. Metode Basin - PLOAD berhasil menujukkan bahwa dalam suatu wilayah administrasi kelurahan maka beban pencemar sumber bukan terpusat akan berhubungan lurus dengan luas wilayah dan area terbagun. Model menunjukkan adanya suatu perbandingan nilai beban pencemaran di setiap kelurahan untuk dilakukan perbandingan. Kelurahan Pajang Kecamatan Laweyan. memempati urutan teratas dalam jumlah sumber pencemar dengan nilai $95 \mathrm{~kg} /$ tahun untuk CU, 1,097 $\mathrm{kg} /$ tahun untuk fosfat, $534 \mathrm{~kg} /$ tahun untuk nitrat dan 2,042 kg/tahun untuk COD. Selain itu kualitas air juga dipengaruhi oleh sumber terpusat berupa jumlah industri batik seperti di Kelurahan Pajang, Sondakan dan Laweyan. Berdasarkan hasil uji laboratorium nilai COD, Nitrat, Fosfat maupun tembaga, hampir keseluruhan masih dibawah baku mutu Kelas IV menurut PP no. 82 tahun 2001. Penataan tata ruang menjadi kunci penting dalam prediksi jumlah beban pencemar. Maka review alokasi penataan ruang dapat menjadi cara dalam mengurangi beban pencemaran yang masuk menuju sungai.

DAFTAR PUSTAKA

CH2M HILL .2001. 'CALCULATION OF EMC VALUES FOR A UK APPLICATION Section', pp. 58-70.

Correll, D. L. .1998. 'Role of Phosphorus in the Eutrophication of Receiving Waters: A Review, The', J. ENVIRON.QUAL, 27(MARCHAPRIL), pp. 261-266.

Dani, T., Suripin and Sudarno .2015. 'Analisis Daya Tampung Beban Cemar Di Das Bengawan Solo Segmen Kota Surakarta Dan Kabupaten Karanganyar Dengan Model Qual2Kw', Jurnal IImu Lingkungan, 13(2), pp. 92-102-8907. 
HDR .2008. 'Final Report Gap Creek Watershed Water Quality Improvement', (November).

Imtiyaz, I., Rezagama, A. and Luvita, V. .2016. 'Pengolahan BOD, COD, TSS dan $\mathrm{PH}$ pada Limbah Industri MSG (Monosodium Glutamate) Menggunakan Teknologi Advanced Oxidation Process $\left(\mathrm{O}_{3} / \mathrm{H}_{2} \mathrm{O}_{2}\right.$ dan Fenton)', 5(1), pp. 1-9.

Jeff $P$, L. .2004. 'Review of Published Export Coefficient and Event Mean Concentration (EMC) Data', Wetlands Regulatory Assistance Program, (September).

Lee, K. S., Chung, E. S. and Kim, Y. O. .2008. 'Integrated watershed management for mitigating streamflow depletion in an urbanized watershed in Korea', Physics and Chemistry of the Earth, 33(5), pp. 382-394. doi: 10.1016/j.pce.2008.02.033.

Lin, C. $d k k$. .2016. 'Detection of sensitive soil properties related to non-point phosphorus pollution by integrated models of SEDD and PLOAD', Ecological Indicators. Elsevier Ltd, 60, pp. 483-494. doi: 10.1016/j.ecolind.2015.07.023.

Oliveira, B. dkk. .2012. 'Application of Qual2Kw model as a tool for water quality management: Cértima River as a case study', Environmental Monitoring and Assessment, 184(10), pp. 6197-6210. doi: 10.1007/s10661-011-2413-z.

Ongley, E. D., Xiaolan, Z. and Tao, Y. 2010. 'Current status of agricultural and rural non-point source Pollution assessment in China', Environmental Pollution. Elsevier Ltd, 158(5), pp. 1159-1168. doi: 10.1016/j.envpol.2009.10.047.

PAPPAS, V.2013. 'Databases and Geographic Information Systems Databases and Geographic Information Systems Bases de Bases de Donnees Donnees - -SIG SIG', p. 10.
Prayitno, H. .2006. 'Pengaruh Pasokan Limbah Cair Tekstil PT. Batik Keris Sukoharjo terhadap Perubahan Suhu, pH, DO, BOD, $\mathrm{NO}_{3}, \mathrm{Ca}, \mathrm{Mg}$ dan Plankton di Sungai Premulung Surakarta', Fakultas Matematika dan IImu Pengetahuan Alam, (3).

Rahmad, R., Yunasfi and Maragunung, D. .2014. 'Tingkat Kandungan Logam Berat Timbal $(\mathrm{Pb})$ dan Tembaga (Cu) di Sungai Belawan Kecamatan Medan Sunggal Kota Medan (Level of Heavy Metal Content of Lead (Pb) and Copper $(\mathrm{Cu})$ in the district of Medan Belawan River Sunggal Medan) Rahmad', pp. 1-10.

RATIDZO, D. 2011. Testing the use of the BASINS PLOAD model to simulate the quality of stormwater runoff from the Kuils River catchment, Cape Town, Testing the use of the BASINS PLOAD model to simulate the quality of stormwater runoff from the Kuils River catchment, Cape Town. University of Cape Town.

Sanusi, H. S. .1994. 'Teluk Pelabuhan Ratu pada Musim Barat dan Timur ( Chemical Characteristic and Fertility of Pelabuhan Ratu Bay Waters at East and West Monsoon )', pp. 93100.

Simon I, P., Argah, H. and S, M. A. .2015. 'Zat Hara (Fosfat, Nitrat), Oksigen Terlarut dan $\mathrm{pH}$ Kaitannya dengan Kesuburan', 1, pp. 43-50.

Sulistiyanto, Wahyu and Astuti, D. 2010. 'Analisis Kualitas Air Sungai Bengawan Solo Wilayah Kota Surakarta'.

USEPA .2001. 'PLOAD version 3.0. GIS Pollutant Loading Application Users Manual', (January), p. 48. Available at: http://water.epa.gov/scitech/datait/m odels/basins/upload/2002_05_10_B ASINS_b3docs_PLOAD_v3.pdf.

Young, D. J. 2006. 'Development of an ArcGIS - Pollutant Load Application (PLOAD) Tool', (August), p. 60. doi: 10.1017/СВO9781107415324.004. 